\title{
Characterization of low density lipoprotein receptor (LDLR) gene mutations in Albania
}

Maria Diakou ${ }^{1,2}$, George Miltiadous ${ }^{1,2}$, Stavroula Xenophontos², Marios Cariolou², Nevila Heta ${ }^{3}$, Irena Korita ${ }^{3}$, Anyla Bulo ${ }^{3}$, Etleva Refatllari³, Eleni Bairaktari³ ${ }^{3}$ Moses Elisaf ${ }^{1}$

1Department of Internal Medicine, Medical School, University of Ioannina, Ioannina, Greece

${ }^{2}$ Molecular Genetics Dept. B-DNA Identification Laboratory, The Cyprus Institute of Neurology and Genetics, Nicosia, Cyprus

3University Hospital Centre "Mother Teresa", School of Medicine, Rr Kavajes, Tirana, Albania

Submitted: 23 July 2009

Accepted: 11 August 2009

Arch Med Sci 2010; 6, 2: 198-200

DOI: 10.5114/aoms.2010.13894

Copyright $\odot 2010$ Termedia \& Banach

\section{Abstract}

Introduction: Familial hypercholesterolaemia $(\mathrm{FH})$ is a clinical syndrome characterised by elevated serum total cholesterol (TCHOL) levels due to an increase in low-density lipoprotein (LDL) cholesterol, by tendon xanthomata and clinical manifestations of ischaemic heart disease in early life. Typically, it results from mutations in the low-density lipoprotein receptor (LDLR) gene. So far, more than 800 mutations have been reported for the $L D L R$ gene and account for $\mathrm{FH}$. The nature of $L D L R$ gene mutations varies among different ethnicities. Until now no mutations of LDLR have been reported in the Albanian population.

Material and methods: We assessed the contribution of the $L D L R$ gene mutations as causes of $\mathrm{FH}$ in an Albanian population. Fifty probands with a clinical diagnosis of $\mathrm{FH}$ were included. We analysed all the exons and the promoter of the $L D L R$ gene by using restriction isotyping or direct sequencing.

Results: Twenty-one patients were heterozygous for the $1646 \mathrm{G}>\mathrm{A}$ mutation (FH Genoa) in exon 11 and 9 patients were heterozygous for the $81 T>C$ mutation in exon 2 of the $L D L R$ gene.

Conclusions: This report describes two $L D L R$ gene mutations accounting for $\mathrm{FH}$ in Albania (1646G>A, 81T>C).

Key words: familial hypercholesterolaemia, low density lipoprotein receptor gene, Albania.

\section{Introduction}

The low-density lipoprotein receptor (LDLR; MIM\# 143890) is a $160 \mathrm{kD}$, cell surface transmembrane protein that facilitates the uptake of plasma LDL primarily into hepatocytes, where it is further catabolised [1]. A genetic defect caused by mutations in the $L D L R$ gene on chromosome 19 results in malfunctioning or insufficient numbers of $L D L R$ molecules, which accounts for the reduced clearance of LDL molecules from the plasma via the receptor-mediated pathway. Low-density lipoprotein is then catabolised via a non-receptor mediated pathway. This abnormality leads to premature development of atherosclerosis. The worldwide heterozygote frequency for $\mathrm{FH}$ is about $1 / 500$. The prevalence of homozygosity is much less, about $1 / 1000,000$. The most common clinical features of $\mathrm{FH}$ are tendon
Corresponding author:

Prof. Moses Elisaf, MD, FRSH

Department of Internal

Medicine

Medical School,

University of loannina

GR 451 10, Ioannina, Greece

Phone: +302651007509

Fax: +302651007507

E-mail:me00521@cc.uoi.gr 
xanthomata, xanthelasma palpebrarum, corneal arcus and ischaemic heart disease. The clinical diagnosis is only confirmed by identification of the mutation in the $L D L R$ gene. However, to our knowledge no mutation has been reported in the Albanian population until now. Knowledge of the mutations in the $L D L R$ gene helps to confirm the clinical diagnosis and also to identify younger affected members in a known FH family. Furthermore, presymptomatic diagnosis and early therapeutic intervention could prevent premature atherosclerosis. Thus, we undertook the present study to characterise the mutations of the $L D L R$ gene in Albanian pedigrees with a clinical diagnosis for heterozygous $\mathrm{FH}$.

\section{Material and methods}

\section{Patient recruitment}

A total of 50 unrelated patients (33 males and 17 females) aged from 11 to 70 years old attending the lipid clinic of the University Hospital Centre "Mother Teresa" with a clinical diagnosis of heterozygous FH participated in the study. The diagnosis of FH was based on William's clinical criteria [2]. In detail, patients with plasma LDL-C levels above $190 \mathrm{mg} / \mathrm{dl}$ and with a family history of tendon xanthomata were considered as FH patients and were recruited into our study. Hypercholesterolaemic patients with the apolipoprotein (apo) B3500 gene mutation were excluded by sequencing of the apo $B$ gene and other secondary causes of hypercholesterolaemia were excluded by history, physical examination and the appropriate laboratory tests including thyroid function (TSH), creatinine, proteinuria and alkaline phosphatase.

\section{Detection of low-density lipoprotein receptor gene mutations}

In all cases, DNA analysis for the LDLR gene was performed. Whole blood was collected from all patients after informed consent. DNA was extracted from the whole blood specimens as described previously [3]. PCR was carried out using 50 ng DNA isolated from each individual. All $L D L R$ gene exons and the promoter were amplified as described previously [4]. PCR was carried out using an MJR PTC-100 thermal cycler. Restriction enzyme isotyping was first used for detecting previously described LDLR gene mutations in northwestern Greece, an area which is next to Albania [5, 6]. Automated sequencing was performed using the Applied Biosystems "Big Dye Terminator Cycle Sequencing Ready Reaction Kit" as instructed by the manufacturer (Applied Biosystems). Both forward and reverse sequencing were performed to confirm our findings. The sequenced products were then separated by capillary electrophoresis using an ABI PRISM 3130 Genetic Analyzer. Sequencing Analysis and Sequence Navigator software were used to analyse the collected data and compare them with the published reference sequence of the $L D L R$ gene.

\section{Results}

This study led to the identification of 2 LDLR gene mutations, which to our knowledge are the first described in the Albanian population. Twentyone patients were heterozygous for the $1646 \mathrm{G}>\mathrm{A}$ mutation (FH Genoa) in exon 11 and 9 patients were heterozygous for the $81 \mathrm{~T}>\mathrm{C}$ mutation in exon 2 . No patient was found to be homozygous for the above 2 mutations. The frequency of the above mutations is shown in Table I, and the lipid profile of the patients carrying the same mutation is shown in Table II. There were no significant differences in the values of serum lipid parameters or in the prevalence of tendinous xanthomas, xanthelasma palpebrarum, corneal arcus and ischaemic heart disease among heterozygous patients carrying these $2 L D L R$ gene mutations.

Table I. $L D L R$ gene mutations found in Albanian pedigrees $(n=50)$

\begin{tabular}{|lccccc|}
\hline Exon & $\begin{array}{c}\text { Nucleotide } \\
\text { change }\end{array}$ & $\begin{array}{c}\text { Amino acid } \\
\text { change }\end{array}$ & $\begin{array}{c}\text { Number of } \\
\text { patients }\end{array}$ & $\begin{array}{c}\text { Percentage } \\
\text { of study group }\end{array}$ & $\begin{array}{c}\text { Detection } \\
\text { assay }\end{array}$ \\
\hline 2 & $81 T>C$ & C5W & 9 & $18 \%$ & Direct sequencing \\
\hline 11 & $1646 \mathrm{G}>\mathrm{A}$ & G528D & 21 & $42 \%$ & Direct sequencing \\
\hline
\end{tabular}

Table II. Lipid profile of the study population

\begin{tabular}{|lccccc|}
\hline Mutation & Age $^{*}$ & Total cholesterol $^{\star *}$ & Triglycerides $^{\star \star}$ & HDL $^{\star *}$ cholesterol & LDL $^{* \star}$ cholesterol $^{*}$ \\
\hline $81 T>C$ & $41 \pm 11$ & $358 \pm 48$ & $130 \pm 27$ & $54 \pm 12$ & $282 \pm 38$ \\
\hline $1646 \mathrm{G}>\mathrm{A}$ & $43 \pm 12$ & $362 \pm 75$ & $128 \pm 48$ & $56 \pm 15$ & $280 \pm 49$ \\
\hline
\end{tabular}

*years, **mean value $\pm S D[\mathrm{mg} / \mathrm{dl}]$ 


\section{Discussion}

We undertook the present study to characterise the mutations in the $L D L R$ gene in Albanian pedigrees with heterozygous FH. Forty-two percent of the patients possessed the 1646G>A LDLR gene mutation, located in exon 11. The LDLR activity is known to be reduced to $2 \%$. The same mutation has previously been described in an Italian $\mathrm{FH}$ family [7] and in Greek FH patients [5, 6]. The 81T>G LDLR $(5 \mathrm{C}>\mathrm{W})$ gene mutation, located in exon 2 , has a frequency of $18 \%$ in the Albanian population. The activity of the $L D L R$ resulting from the $81 T>G$ mutation is reported to be reduced to $5-15 \%$. The mutation was first described in Americans [8] and also in Croatian and English $\mathrm{FH}$ patients [Database of $L D L R$ gene mutations in $\mathrm{FH}$ : http://www.ucl.ac.uk/fh]. Furthermore, the mutation $81 T>G$ has also been previously described in the population of northwestern Greece [9].

Although the clinical criteria for the diagnosis of heterozygous $\mathrm{FH}$ were met in all participants, not all of the participants were genetically diagnosed as $\mathrm{FH}$ heterozygotes. This finding can be explained by the fact that we did not check for other genetic syndromes that mimic $\mathrm{FH}$ such as familial hypercholesterolaemia type III and autosomal recessive hypercholesterolaemia.

The identification of these gene mutations will improve genetic diagnosis of $\mathrm{FH}$ in the Albanian population. From a public health point of view, the knowledge of these mutations and their distribution may favour the development of tailed information and screening programmes based on these data [10]. The improvement of genetic diagnosis is of paramount importance for the early diagnosis of new members of an affected family or new probands in Albania. Therapeutic intervention at this early stage is effective for the primary prevention of coronary artery disease. Combination therapy with a statin and ezetimibe is now available for more plasma LDL-C reductions [11]. Furthermore, the fact that gene therapy is not far away makes the knowledge of the pathogenic mutations in various populations of paramount importance.

In conclusion, to our knowledge, this study describes for the first time details of the $L D L R$ gene mutations causing $\mathrm{FH}$ in an Albanian population. However, this is a preliminary publication and more research is needed for the Albanian $\mathrm{FH}$ data to be extended and effective in preventing cardiovascular disease.

\section{Acknowledgments}

We thank all the families that participated in the present project.

\section{References}

1. Goldstein JL, Brown MS. Familial hypercholesterolaemia. In: Scriver CR, Beaudet AL, Sly WS, Valle D (eds). The Metabolic Basis of Inherited Diseases. New York, McGrawHill 1989; 1215-50.

2. Williams RR, Hunt SC, Schumacher MC, et al. Diagnosing heterozygous familial hypercholesterolemia using new practical criteria validated by molecular genetics. Am J Cardiol 1993; 72: 171-6.

3. Miller SA, Dykes DD, Polesky HF. A simple salting out procedure for extracting DNA from human nucleated cells. Nucleic Acids Res 1988; 16: 1215.

4. Hobbs HH, Brown MS, Goldstein JL. Molecular genetics of the LDL receptor gene in familial hypercholesterolemia. Hum Mutat 1992; 1: 445-66.

5. Traeger-Synodinos J, Mavroidis N, Kanavakis E, et al. Analysis of low density lipoprotein receptor gene mutations and microsatellite haplotypes in Greek FH heterozygous children: six independent ancestors account for $60 \%$ of probands. Hum Genet 1998; 102: 343-7.

6. Miltiadous G, Elisaf M, Xenophontos S, Manoli P, Cariolou AM. Segregation of a novel LDLR gene mutation (I430T) with familial hypercholesterolemia in a Greek pedigree. Hum Mut 2000; \#147 Online.

7. Hobbs HH, Russell DW, Brown MS, Goldstein JL. The LDL receptor locus and familial hypercholesterolemia: mutational analysis of a membrane protein. Annu Rev Genet 1990; 24: 133-70.

8. Leitersdorf E, Reshef A, Meiner V, et al. A missense mutation in the low density lipoprotein receptor gene causes familial hypercholesterolemia in Sephardic Jews. Hum Genet 1993; 91: 141-7.

9. Miltiadous $\mathrm{G}$, Elisaf M, Bairaktari $\mathrm{H}$, Xenophontos SL, Manoli P, Cariolou MA. Characterization and geographic distribution of the low density lipoprotein receptor (LDLR) gene mutations in Northwestern Greece. Hum Mutat 2001; \#411 Online.

10. Miltiadous G, Cariolou M, Elisaf M. Familial hypercholesterolaemia: taking advantage of a founder effect for early diagnosis and treatment. Community Genet 2001; 4: 123-4.

11. Kalogirou M, Tsimihodimos V, Saougos V, Lagos K, Tselepis A, Elisaf M. Effect of ezetimibe on lipoprotein subfraction concentrations: the role of atorvastatin pretreatment. Arch Med Sci 2007; 3: 344-50. 